\title{
n-EXPONENTIAL CONVEXITY OF DIVIDED DIFFERENCES AND RELATED STOLARSKY TYPE MEANS
}

\author{
Gulam Roqia, Josip PeČarić And Ana Vukelić
}

Abstract. In this paper we consider functionals with divided differences. Two of them use majorization type results, where one is related with Schur convexity. The others are related to Jensen inequality and Hermite-Hadamard inequalities. We use them in studying Stolarsky type means. A method of producing $n$-exponentially convex functions is applied using divided differences. Mathematics subject classification (2010): 26D15, 26D20, 26D99.

Keywords and phrases: Divided differences, $n$-convex function, majorization, Schur convex function, means, $n$-exponentially convexity.

\section{REFERENCES}

[1] G. Andrews, The Theory of Partitions, Encyclopedia Math. Appl. 12, Addison-Wesley, Reading, MA, 1976.

[2] M. AnWAR, J. PeČArIĆ, New means of Cauchy's type, J. Inequal. Appl. 2008 (2008), Art. ID 163202, 10 pages.

[3] K. E. AtKinson, An Introduction to Numerical Analysis, 2nd ed., Wiley, New York, 1989.

[4] W. Ehm, M. G. Genton, T. Gneiting, Stationary covariance associated with exponentially convex functions, Bernoulli 9, 4 (2003), 607-615.

[5] R. FARWIG, D. ZWICK, Some divided difference inequalities for $n$-convex functions, J. Math. Anal. Appl. 108 (1985), 430-437.

[6] J. JAKŠETIĆ, J. PEČARIĆ, Exponential convexity method, J. Convex Anal. 20, 1 (2013), 181-197.

[7] P. A. Macmahon, Combinatory Analysis, I, II, Chelsea, New York, 1960.

[8] Z. Pavić, J. PeČAriĆ, A. Vukelić, Means for divided differences and exponential convexity, Mediterr. J. Math. 9, 1 (2012), 187-198.

[9] Z. PAVIĆ, J. PEČARIĆ, A. Vukelić, Exponential convexity and Jensen inequality for divided differences, J. Math. Ineq. 5, 2 (2011), 157-168.

[10] Z. PAVIĆ, J. PeČArić, A. Vukelić, Exponential convexity for divided differences related to Hermite-Hadamard inequalities, Asian-European J. Math. 5, 4 (2012), 1250056 (16 pages).

[11] J. E. PEČARIĆ, An inequality for 3-convex function, J. Math. Anal. Appl. 90 (1982), 213-218.

[12] J. E. PeČArić, F. Proschan And Y. L. Tong, Convex functions, partial orderings, and statistical applications, Mathematics in science and engineering, 187, Academic Press, 1992.

[13] J. PeČARIĆ, M. Rodić Lipanović, On an inequality for divided differences, Asian-European J. Math. 1, 1 (2008), 113-120.

[14] J. E. PeČARIĆ, D. ZWICK, n-Convexity and Majorization, Rocky Mountain J. Math 19 (1989), $303-$ 311.

[15] J. PeČARIĆ, J. PERIĆ, Improvements of the Giaccardi and the Petrović inequality and related results, An. Univ. Craiova Ser. Mat. Inform., 39, 1 (2012), 65-75.

[16] P. M. Vasić, Lu. R. Stanković, On some inequalities for convex and g-convex functions, Univ. Beograd. Publ. Elektrotehn. Fak. Se. Mat. Fiz. 412-460 (1973), 11-16.

[17] D. V. Widder, The Laplace transform, Princeton Univ. Press, New Jersey, 1941.

[18] D. ZwICK, A divided difference inequality for n-convex functions, J. Math. Anal. Appl. 104 (1984), $435-436$. 